\title{
Application of the Modern Analog Technique (MAT) of Sea Surface Temperature Estimation to Middle Pliocene North Pacific Planktonic Foraminifer Assemblages
}

\author{
Harry J. Dowsett and Marci M. Robinson
}

\begin{abstract}
Seventy-two samples from Deep Sea Drilling Project Sites 445 and 463 and Ocean Drilling Program Site 769 from the northwest Pacific Ocean were compared to 499 modern core top Pacific Ocean samples using the squared chord distance dissimilarity measure. Many samples show high levels of dissimilarity that can be explained by pervasive dissolution and/or evolution changing the composition of the fossil assemblages. Weighted averages of winter and summer sea surface temperatures (SST) from the nearest five modern analogs of each fossil-bearing sample were used to estimate Pliocene SST. Results show little to no middle Pliocene warming at low latitudes (Site 769) and warming of $2^{\circ} \mathrm{C}$ to $4^{\circ} \mathrm{C}$ in winter and possibly $1^{\circ} \mathrm{C}$ in summer just north of the Philippine Sea (Site 445). These data, when combined with other estimates of Pliocene SST in the northwest Pacific, suggest an enhanced meridional oceanic heat flow, similar to that found in the North Atlantic during the same part of the Pliocene.
\end{abstract}

Harry J. Dowsett and Marci M. Robinson, United States Geological Survey, 955 National Center, Reston, Virginia 20192

Key Words: Pliocene, planktonic foraminifera, SST, Pacific, analog

\section{INTRODUCTION}

There are several ways to estimate past sea surface temperature (SST) and other paleoceanographic parameters using fossil plankton. Oxygen isotope measurements of delta ${ }^{18} \mathrm{O}$ in foraminiferal tests provide estimates of sea-water delta ${ }^{18} \mathrm{O}$ at the time the carbonate was secreted by the organism. These values can be used to estimate ambient water temperature at the time of secretion as long as assumptions are made about vital effects and the salinity of the sea water (Emiliani 1955, 1966, 1972). Due to uncertainties in ice volume history-in the Neogene primarily the state of Antarctic iceisotopic estimates of temperature must be viewed with some degree of uncertainty. Paleoceanographers have also used the distribution of fossil foraminifers to estimate past SST. Whether based on qualitative or quantitative techniques, these estimates depend upon a thorough knowledge of the modern distribution of taxa in the world ocean, and the assumption that specific taxa have not changed ecological tolerances over time. These ideas led Imbrie and Kipp (1971) and Kipp (1976) to develop the transfer function technique which was the foundation of the Climate, Long Range Investigation and Mapping (CLIMAP) Project (CLIMAP 1976, 1981, 1984). As part of the Pliocene Research, Interpretation, and Synoptic Mapping (PRISM) Project, various statistical methods have been developed to transform Pliocene faunal census data into 
estimates of physical oceanographic parameters such as sea surface temperature (SST) and salinity (Dowsett and Poore 1990, Cronin and Dowsett 1990, Dowsett 1991). This paper focuses on the Modern Analog Technique (MAT) and its application to prePleistocene planktonic foraminifer assemblages. The MAT method has been discussed in detail by Hutson (1979), Prell (1985), and Anderson et al. (1989) who applied it to late Pleistocene applications planktonic foraminiferal data, but there are relatively few applications (Dowsett 1996, Andersson 1997) available to illustrate the technique's use with pre-Pleistocene samples. In this paper we review the methodology and apply the MAT technique to Pliocene sediments in the North Pacific to evaluate its usefulness for pre-Pleistocene SST estimation.

\section{MODERN ANALOG TECHNIQUE (MAT)}

The Modern Analog Technique (MAT) quantifies faunal changes within deep-sea cores in terms of modern oceanographic conditions (Hutson 1979). The method uses a measure of faunal dissimilarity to compare down-core samples to each reference sample in a modern oceanographic database. Working with late Pleistocene planktonic foraminifers, Hutson (1979) originally used cosine-theta distance to match modern Indian Ocean samples to late Pleistocene age core samples and then employed a weighted average of sea surface temperature and salinity associated with the closest analogs of each core sample to derive down-core environmental estimates. Overpeck et al. (1985) investigated the responsiveness of eight dissimilarity coefficients to palynological changes caused by differences in modern vegetation and applied the MAT technique to late Quaternary pollen diagrams from eastern North America. Their analyses suggested that whereas all coefficients give roughly similar results, signal-tonoise measures performed better than unweighted or equal-weight dissimilarity coefficients (Overpeck et al. 1985).

After experimentation with different dissimilarity coefficients we chose the squared chord distance (SCD) measure for our study:

$$
d_{i j}=\sum_{k}\left(p_{i k}{ }^{1 / 2}-p_{j k}{ }^{1 / 2}\right)^{2}(1)
$$

where $d_{i j}$ is the squared chord distance between two multivariate samples $i$ and $j$, and $p_{i k}$ is the proportion of species $k$ in sample $i$. Squared chord distance values can range from 0.0 to 2.0, with 0.0 indicating identical proportions of species within the samples being compared. To illustrate the technique, a foraminifer census from a mid-latitude North Atlantic modern (core top) sample was compared to 223 other modern North Atlantic samples. Figure 1A 
shows that all modern samples converge on the temperature of the test sample. Averaging the observed February SST associated with the ten nearest analogs produces an "estimated" SST of $18.43^{\circ} \mathrm{C}$. The width of the vertical blue band indicates the standard deviation $\left(\sigma= \pm 1.15^{\circ} \mathrm{C}\right)$ of the values that make up the estimated SST.

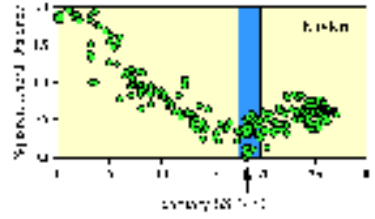

As mentioned above, this technique has been used by others (e.g., Prell 1985, Anderson et al. 1989) to estimate late Pleistocene SST using planktonic foraminifer census data. When working with older (e.g., Pliocene) samples, the closest analogs are somewhat more distant than when working with younger material (lkeya and Cronin 1993, Dowsett 1996, Andersson 1997). This is illustrated in Figure

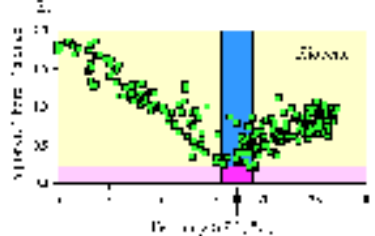

Figure 1.

$1 \mathrm{~B}$ by the horizontal pink band which indicates that no modern sample has a squared chord distance less than 0.22 units from the Pliocene sample selected for comparison. Nevertheless, the distribution of points on Figure 1B clearly suggests that the most similar samples in the modern database range between $16^{\circ}$ and $19^{\circ} \mathrm{C}$. Averaging the 10 nearest analogs gives a temperature estimate of $17.25^{\circ} \mathrm{C}(\sigma=$ $\left.\pm 1.51^{\circ} \mathrm{C}\right)$.

\section{Another illustration of MAT is shown in Figure 2.}

Modern North Atlantic latitudinal SST gradients for cold and warm seasons were developed from observed SST at four sites. Core-top faunal data from these four sites were analyzed using MAT and the SST estimates plotted in Figure 2A. For comparison, four Pliocene samples representing approximately $2.795 \mathrm{Ma}$ at different latitudes were analyzed using MAT and the SST estimates were used to draw Pliocene gradients (Fig. 2B). Whereas it is difficult to compare the gradients based upon so few sites, it is worthwhile to note that

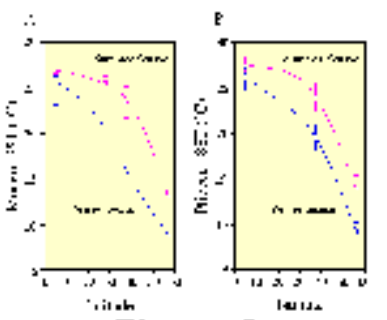

Figure 2. the Pliocene gradients are offset from the modern gradients which are generally cooler. The Pliocene gradients are generally less steep at low and mid-latitudes when compared to the modern gradients. Also, seasonality (measured as summer season minus winter season) is estimated to be greater in modern climates than in the Pliocene. These results are reasonable and fit well with previous studies of the MidPliocene of the North Atlantic which used independent methods of inference (Dowsett et al. 1992, Dowsett, Barron and Poore 1996). We conclude that despite the lower levels of similarity, the MAT can provide a powerful method for transferring modern oceanographic conditions to Pliocene samples.

Application of this technique to Pliocene sequences requires several additional considerations. First, Pliocene sequences contain taxa now extinct and therefore not in the modern database. Also, there are taxa present in the modern database that have evolved since the Pliocene. Dowsett and Poore (1990) and Dowsett (1991) explored various ways to regroup modern planktonic foraminifers into categories that could be used as far back as the early Pliocene. These studies found that different members of the genus Globigerinoides, excepting Globigerinoides sacculifer, could be grouped into a single tropical category with little loss of information. Likewise, at high latitudes, 
members of the genus Neogloboquadrina could be grouped together to form cold and warm end members of that genus. For Pliocene samples, several ancestor-descendent pairs were identified, and the Pliocene ancestors were assumed to have the same environmental tolerances as their modern descendants. These species groupings allowed more direct comparisons of modern and Pliocene faunas of the North Atlantic. Similar groupings are necessary to both modern and Pliocene data being compared by dissimilarity measures (see below).

\section{MATERIALS AND METHODS}

Modern Database. The Modern Analog Technique requires access to a large modern database that captures much of the variability present in modern faunas. Our modern Pacific database (Appendix) is a component of the global planktonic coretop database described by Prell (1985) and used by many workers. The Pacific database (Fig. 3 )

has 499 coretop faunal analyses from the work of Thompson (1976, 1981), Parker and Berger (1971), Coulborn et al. (1980), and some unpublished data. The samples are distributed from $47^{\circ} \mathrm{N}$ to $64^{\circ} \mathrm{S}$ and represent winter and summer temperatures between $0^{\circ} \mathrm{C}$ and $30.3^{\circ} \mathrm{C}$. For this study we regrouped the modern faunal data into the same species groups as Dowsett and Poore (1990) and Dowsett (1991) with the following changes. Species with no more than one individual in a sample were deleted from the dataset at the outset. Dowsett and Poore (1990) combined sinistral and dextral

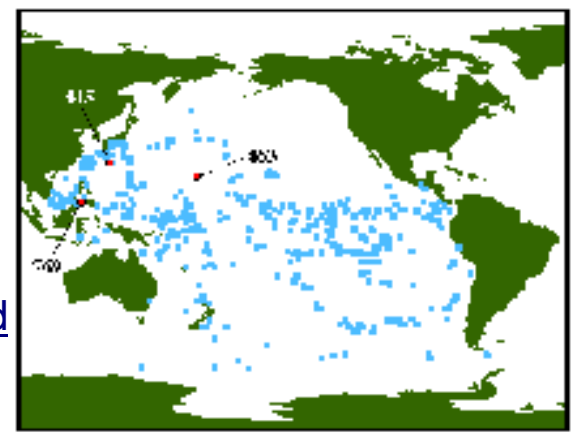

Figure 3 . coiling varieties of Neogloboquadrina pachyderma with the artificial $N$. pachyderma - N. dutertrei intergrade category of Kipp (1976) to create a "cold" end member Neogloboquadrina category for the North Atlantic. The modern "warm" Neogloboquadrina end member consists of $N$. dutertrei which is important in low-latitude and gyre-margin upwelling regions (Dowsett 1991). In this study we chose to leave the N. pachyderma categories and $N$. dutertrei - N. pachyderma category as distinct elements of the modern fauna. These conventions resulted in 21 counting categories (Table 1).

Sample Preparation, Counting Techniques and Taxonomy. To test the MAT, three Pliocene sequences were selected from the western North Pacific (Fig. 3). These deepsea cores represent a range of oceanographic conditions and thus provide a good test of the MAT technique.

The samples used in this study were washed using low temperature (isotope) procedures. Sediment samples were dried in an oven at less than or equal to $50^{\circ} \mathrm{C}$ and weighed. The dried bulk sample was disaggregated in a beaker with warm tap water and about $2 \mathrm{ml}$ of dilute Calgon ${ }^{\mathrm{TM}}$ solution ( $5 \mathrm{gm}$ Calgon ${ }^{\mathrm{TM}}$ to 1 liter water). The beaker was agitated on a vibrating hot plate without heating. Samples were then washed through a 63 micron sieve using a fine spray hose and dried in an oven at less than or equal to $50^{\circ} \mathrm{C}$. Ocean Drilling Program Hole 769B samples required an additional treatment with $\mathrm{NaCO}_{3}$ added to the wash in order to obtain clean specimens. Weights 
were then obtained for the fine and coarse fractions of each sample.

A split of 300 to 350 planktonic foraminifer specimens was obtained from the $>149$ micron size fraction of each sample using a Carpco ${ }^{\mathrm{TM}}$ sample splitter. Specimens were identified, sorted, and fixed to a standard 60-square micropaleontological slide. The taxonomic names used in Tables $2, \underline{3}$, and $\underline{4}$ are summarized in Polanco and Dowsett (1993) and Dowsett and West (1993). In general, our taxonomic concepts follow Parker $(1962,1967)$ and Blow (1969). Pliocene census data were retabulated and converted to percent using the same counting categories used in the modern database. Deep Sea Drilling Project and ODP sample designations are abbreviated as core-section, depth within section in centimeters (e.g., 10-5, $34=$ core 10, section $5,34 \mathrm{~cm}$ below top of section 5). The depth column lists depth of sample below sea floor in meters. Wherever ages are provided they refer to the Berggren et al. (1985) time scale.

DSDP Site 445, Hole 445. Deep Sea Drilling Project Hole 445 was drilled on the Daito Ridge in the Northern Philippine Sea $\left(25.52^{\circ} \mathrm{N}, 133.20^{\circ} \mathrm{E}\right)$ in 3377 meters of water. The upper $150 \mathrm{~m}$ of sediment recovered at Hole 445 consists of nannofossil ooze with interbedded foraminifer-nannofossil oozes (Klein et al. 1980). Calcareous microfossils are, over certain intervals, abundant and well preserved at this locality (Echols 1980, Okada 1980). From selected microfossil datums (Echols 1980, Okada 1980), we determined that cores 10 through 12 represent the middle Pliocene. Twenty-three samples between the bottom of Core 8 and the top of Core 13 were chosen for this study. Graphic correlation was used (Fig. 4) to determine the relationship between depth at Hole 445 and the composite standard reference section (CSRS) of Dowsett (1989a,b). Depth in Hole 445 can be converted to composite units (cu) using the equation:

$$
y=8.48+0.874 x, \text { for } x>20 \text { and } x<120(2)
$$

where $\mathrm{x}$ is depth in Hole 445 in meters and $\mathrm{y}$ is composite unit position of the CSRS of Dowsett (1989a, $\underline{b})$. This line of correlation is well constrained down through Core 10 by the last occurrences of Helicosphaera selli, Calcidiscus macintyrei, Discoaster pentaradiatus, Dentoglobigerina altispira, and Sphaeroidinellopsis spp., and the first occurrence of Globorotalia truncatulinoides. Equation (2) is used between 20 and $120 \mathrm{~m}$ sub-bottom. Because the CSRS of Dowsett $(1989 a$ a,$\underline{b})$ exhibits a nearly linear fit to absolute age, CSRS position can be converted to absolute age using the equation:

$$
y=0.354+0.034 \times\left(r^{2}=0.99\right)(3)
$$

where $y$ is age in Ma (Berggren et al. 1985) and $x$ is composite unit position of the CSRS. Applying equations (2) and (3) above to the samples chosen for this study indicates an age range of $3.82 \mathrm{Ma}$ to $2.56 \mathrm{Ma}$. 
Faunal census data for Hole 445 is given in Table 2 (Dowsett and West 1993). The fauna is a typical Pliocene subtropical assemblage with significant proportions of Globigerinoides obliquus, Globigerinoides ruber, Globigerinoides sacculifer, Globorotalia crassaformis, Globorotalia menardii, Globigerina woodi, Globigerina incisa, andNeogloboquadrina acostaensis. Large numbers of fragments in some samples are correlated with higher percentages of benthic foraminifers and are suggestive of increased dissolution.

DSDP Site 463, Hole 463. Hole 463 is located in the central North Pacific on the mid-Pacific Mountains at $21.35^{\circ} \mathrm{N}$ and $174.66^{\circ} \mathrm{E}$ in 2525 meters of water (Fig. 3). The upper $50 \mathrm{~m}$ of Hole 463 consists of highly disturbed, bioturbated, and sometimes soupy nannofossil ooze (Thiede and Vallier et al. 1981). The stratigraphic distribution of foraminifers (Vincent 1981, Polanco and Dowsett 1993) suggests a very low sediment accumulation rate with the

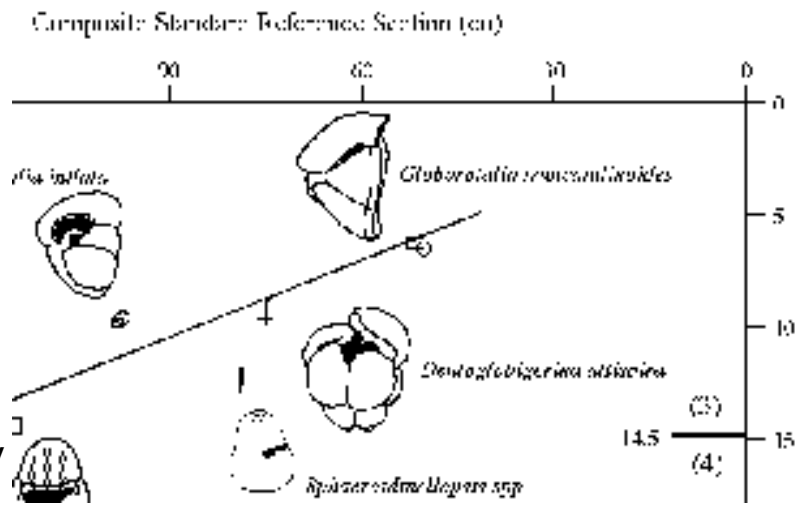
Miocene-Pliocene boundary occurring approximately $25 \mathrm{~m}$ sub-bottom (top of core 4). Twenty-three samples from cores 1 through 4 were processed and analyzed for planktonic foraminifers. Graphic correlation analysis was performed on these samples using planktonic foraminiferal events from Vincent (1981) and Polanco and Dowsett (1993, see Fig. 5). The distribution of events in Figure 5 indicates a "channel" (Shaw 1964) in which the line of correlation (LOC) can be placed. The low number of events results in a fairly broad channel, and the LOC shown in Figure 5 represents only a general correlation. This LOC can be meaningfully applied between about $19 \mathrm{~m}$ and $5 \mathrm{~m}$ sub-bottom. Using the equations of the LOC:

$$
\begin{gathered}
y=-20.94+10.84 x \text { for } x<14.5(4) \\
y=78.00+2.8 x \text { for } x>14.5(5)
\end{gathered}
$$

and equation (3) above, absolute ages can be derived for most of the samples in the census data set. This age model shows our sample spacing to be inadequate to capture any of the oceanographic variability known to exist at Milankovitch periodicities during the Pliocene.

Planktonic foraminifer census data for Hole 463 are presented in Table 3 (Polanco and Dowsett 1993). These samples are dominated by Globigerinoides obliquus, Globigerinoides ruber, Globigerinoides sacculifer, Dentoglobigerina altispira, Globigerina woodi, Orbulina universa, and Sphaeroidinellopsis spp. High numbers of fragmented specimens and high percentages of benthic foraminifers in some samples suggest increased dissolution.

ODP Site 769 , Hole $769 \mathrm{~B}$. Hole $769 \mathrm{~B}\left(8.78^{\circ} \mathrm{N}, 121.29^{\circ} \mathrm{E}\right)$ is located on the 
southeastern flank of the Cagayan Ridge in the Sulu Sea in $3643 \mathrm{~m}$ of water (Fig. 3). The upper 18 cores recovered nearly $170 \mathrm{~m}$ of pelagic biogenic carbonate sediment and hemipelagic clays. Planktonic foraminifers are abundant and fair to moderately wellpreserved in these samples with preservation diminishing due to increased dissolution downcore.

Rangin et al. (1990) interpreted the paleomagnetic stratigraphy to indicate the GaussMatuyama Chron boundary at 114.5 mbsf. The top of the Kaena subchron occurs at

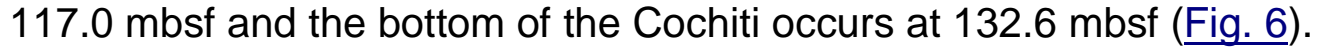

We interpolated between these boundaries using the Berggren et al. (1985) time scale to derive ages for 26 samples from cores 13, 14 (mid Gauss) and 18. This age model suggests these samples are more-or-less equally distributed between about 3.4 and $2.3 \mathrm{Ma}$ with the core 18 samples clustering near 5.3 Ma. Planktonic foraminifer biostratigraphy generally supports these age assignments.

Planktonic foraminifer census data for Hole 769B are given in Table 4 (Polanco and Dowsett 1993). The assemblage is typical of tropical Pacific assemblages with high numbers of Globigerinoides, Globorotalia, and warm water Neogloboquadrina species.

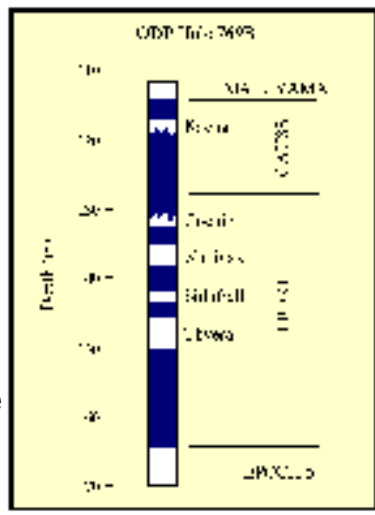

Figure 6.

Fragment data was not generated for Hole 769B, but the high

percentages of benthic taxa in many samples with very low numbers of planktonic specimens per $10 \mathrm{cc}$ of raw material are indicative of severe dissolution.

\section{RESULTS}

The Modern Analog Technique (MAT) was applied to the planktonic foraminiferal assemblages from Sites 445, 463, and 769 to estimate February and August SST. Tables 5 (5a samples 1-100, 5b samples 101-199, 5c samples 200-299, $5 \mathrm{~d}$ samples 300-399, 5 e sample 400-499), 6 (6a samples 1-100, 6b samples 101-199, 6c samples 200-299, $\underline{6 \mathrm{~d} \text { samples 300-399, }}$ 6e samples 400-499), and $7 \underline{7 \mathrm{a} \text { samples } 1-100}$, $\underline{7 \mathrm{~b}}$ samples 101-199, 7c samples 200-299, 7d samples 300-399, 7e samples 400499)show the squared chord distance (SCD) between each sample from the Pliocene sequences and the 499 modern coretop samples. Table 8 summarizes the analyses by showing the minimum, maximum, mean and standard deviation of the lowest SCD values for each site. Distance to the closest analogs of Site 445 samples range between 0.19 and 0.51 with a mean of 0.27 . 
The SCD values from sites 463 and 769 have a wider range $(0.07$ to $\sim 0.60)$, the mean is slightly higher $(\sim 0.30)$, and the standard deviation is twice that of Site 445 samples. Table 9 gives SCD between each sample from the three sites and the closest modern analog, the weighted average February and August SST values, and the standard deviations of those values. To generate SST we used the weighted mean of winter and summer SST associated with the five closest analogs to each Pliocene sample. An SCD value of 0.26 was used as a cutoff for analogous samples. Inspection of faunal

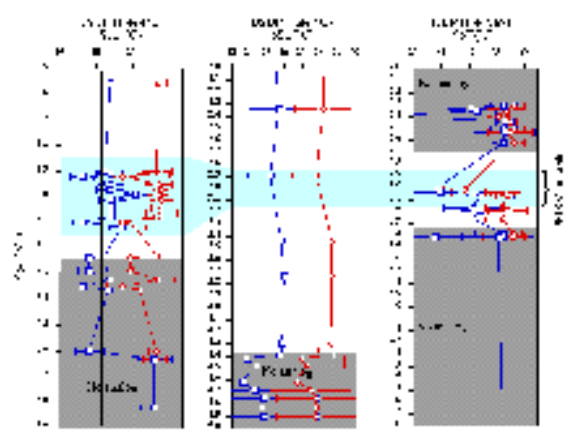

Figure 7 . spectra at a range of distances indicates that samples with distances greater than 0.26 are distinctly dissimilar. On Table 9 and Figure 7, gray bands are used to highlight samples and SST estimates with SCD values $=0.26$. These are referred to as "no analog" samples.

Below sample 11-2, 45 (3.23 Ma), Site 445, SCD values are generally higher, indicating less similarity between Pliocene faunal assemblages and modern Pacific assemblages. Based upon the numbers of planktonic fragments recovered in each sample, carbonate dissolution increases between samples 11-2, 74 (3.24 Ma) and 13-2, 108 (3.82 Ma) relative to Core 10 samples. The only detectable faunal change is a down-core increase in abundance of Globorotalia crassaformis to levels greater than that in any modern sample. We conclude the increased dissolution and resultant no analog levels of Globorotalia crassaformis explain the higher SCD values. Alternatively the non-analog abundance of Globorotalia crassaformis could be due to a Pliocene ecological strategy different from that associated with this species today.

Oceanographic characteristics of the nearest analogs to Hole 445 samples indicate Pliocene SST that are generally the same as those of today with two instances of cooling (Fig. 7). The nearest analogs for these cool samples come from a region in the northern part of the Philippine Sea, close to the present location of DSDP Site 445. For the PRISM time slab (3.15-2.85 Ma), the peak averaging technique (Dowsett and Poore 1991) was used to determine an average deviation from modern winter and summer of $+1.9^{\circ} \mathrm{C}$ and $+0.8^{\circ} \mathrm{C}$ respectively.

At Hole 463, samples below 2-6, 31 (4.35 Ma) have high SCD values indicating a "no analog" situation. Samples below this level have greater numbers of benthic foraminifers, but unlike Hole 445, there is no correlation between high SCD values and high numbers of test fragments. The "no analog" samples are marked by a sharp downcore increase in the percentages of Globigerina nepenthes and Orbulina universa and a decrease in the percentages of Globigerinoides. This faunal change (increase in cooler and concomitant decrease in warmer taxa downcore) explains the step-like shift toward warmer temperatures that takes place at 4.4 Ma.

At Hole 769 only Section 6 of Core 13 and the uppermost two sections of Core 14 (3.26 $\mathrm{Ma}-3.01 \mathrm{Ma}$ ) proved suitable for MAT. Generally, the upper samples gave very high $S C D$ values. Those samples with high SCD values have low numbers of planktonic foraminifers and/or large numbers of dissolution resistant forms (Tables 3 and 9). 
Accordingly, we interpret these high SCD values to be the result of dissolution. The samples in cores 14 and 13 that have acceptable SCD values are at or near modern conditions for winter and summer, but show a marked departure toward cooler conditions at 3.0 Ma. The nearest modern analogs of these samples come from near $27^{\circ} \mathrm{N}, 126^{\circ} \mathrm{E}$ in the southern part of the South China Sea.

\section{DISCUSSION}

The MAT is a powerful method of exploring multivariate faunal data and estimating paleoenvironmental conditions. A robust modern data base is of first-order importance in the successful interpretation of paleontological data using the MAT. This study has enabled us to carefully assess the Pacific portion of the global coretop database described by Prell (1985). There are a number of taxonomic problems in this database. For example, differences in taxonomy between workers are evident in the original data (i.e., the faunal slides). The database itself switches between taxonomic counting categories in different regions because of different ideas or original uses for the data. In our implementation of the MAT, data had to be reorganized into a set of categories recognizable in both Pliocene and Holocene deposits. This effectively eliminated most of the minor taxonomic problems.

The distribution of modern samples with respect to the modern environment is also a primary factor for the MAT. Slightly more than $50 \%$ of all Pacific data is within $\pm 10^{\circ}$ of the equator, and the distribution of the remaining data is heavily skewed toward the southern Hemisphere and extreme western North Pacific (see Fig. 3). It is possible that more analogous samples might have been found in other oceans had we chosen to compare our Pliocene data to the entire modern coretop database.

Dissolution is another first-order problem for MAT analysis. Figure 8

shows the relationship between dissolution and SCD for samples from DSDP Site 445. As indicated above, SCD values increase as dissolution preferentially removes the more fragile elements of the assemblage. In general, solution-susceptible taxa represent the warm end members of planktonic foraminifer assemblages.

Therefore, increased dissolution results in cooler SST estimates. This is especially true in tropical assemblages consisting of greater percentages of fragile tests. In low latitudes, minor dissolution can remove large percentages of the assemblage. Conversely, in polar

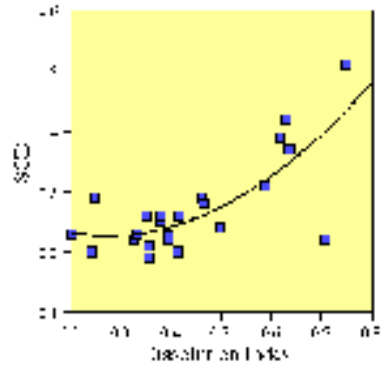

Figure 8. or subpolar regions, planktonic foraminiferal assemblages exhibit much lower diversity and the individual taxa are less prone to dissolution. The robust and dissolution-resistant taxa will not show a discernible change in SCD values unless pervasive dissolution removes large proportions of the assemblage. Even then, unless the dissolution preferentially removes particular taxa the resultant sample may contain proportions analogous to modern samples.

We suggest a sliding scale for acceptable SCD values should be employed, in part, dependent upon latitude. In high-latitude regions anything more than a minor increase in SCD value should be reason to suspect the analysis and question the integrity of the 
original sample. In lower latitude regions where minor dissolution can have a greater effect a larger SCD cutoff should be employed.

The assumption of stability of ecological tolerances over long time scales requires further discussion. Together with related grouping schemes utilized herein, this assumption of stability (basic to most paleontological studies) is subject to criticism. The question is whether in the course of 3 million years of evolution, planktonic foraminifers (or other organisms) adapt in a manner that significantly changes their environmental preferences from those of their ancestors. Since it is nearly impossible to answer this question with certainty, regardless of timescale, the grouping of ancestors with modern descendants and/or fossil taxa with modern taxa having similar morphologies or biogeographic distributions is inherently open to criticism. Nevertheless, various geochemical and isotopic techniques can be employed to determine whether a particular taxon occupies the same position with respect to stable isotopes $\left(\delta^{18} \mathrm{O}, \delta^{13} \mathrm{C}\right)$ over time or whether an ancestor and descendent occupy the same ecological space. Interestingly, these tests also rely on an equally challenging and untestable assumption: that organismic vital effects remain constant over time. In truth, it is often not possible to ascertain whether the assumptions (basic to almost all paleontological research) that must be made to apply MAT to Pliocene age sequences can ever be unequivocally proven correct. Any attempt to infer environmental states from geochemical observations is flawed from the outset by the assumption that a biological system is known in sufficient detail today and that the system did not interact differently with the physical environment in the past.

Irrespective of these considerations, we hold some confidence that the assumptions which, after careful experimentation, we have made are valid, not because the results we obtainedare those we anticipated, but because the same results were obtained with different types of organisms and different quantitative methods. For example, the Pliocene of the northeastern Atlantic Ocean has been intensively studied over the past 15 years. Willard (1994) suggests that during the middle Pliocene areas of Iceland now covered by tundra vegetation were covered by deciduous forest, suggesting temperatures $3^{\circ}$ to $5^{\circ}$ degrees warmer than today. Ostracods were used by Cronin (1991) to show shallow sea-bottom temperatures (the same zone sampled by planktonic foraminifers except closer to the shoreline) off Iceland were warmer than today by about $5^{\circ} \mathrm{C}$ (both winter and summer) during the warm intervals of the middle Pliocene. Dowsett and Poore (1990) and Dowsett et al. (1992) estimated sea surface temperatures to be $3.6^{\circ} \mathrm{C}$ and $7.9^{\circ} \mathrm{C}$ (winter and summer) warmer than today during mid Pliocene "interglacials" in the same region. These three fossil groups (plants, animals and protists) all give more-or-less the same results using three independent techniques. While we agree that assumptions about environmental preferences are inherent in all three studies, it is highly unlikely that these investigations would all suggest the same general answer unless they were sensing on a strong and consistent signal. Therefore, we offer no answers for the critics of paleontologically-based environmental reconstruction, but also hold that through careful integrated analysis using different biological systems one can gain improved confidence in results.

Dowsett et al. (1994) reconstructed winter and summer SST fields of the North Pacific 
from a limited number of data points that showed a step-like increase in SST across the Pacific rather than a smooth gradient, such as that which typifies the modern Pacific.

Our results from Site 769, combined with work done at Sites 573 (Hays et al. 1989), 586 (Jenkins 1992a, b) , 846 (Shackleton et al. 1995) and 806 (Andersson 1997) confirm that low-latitude Pacific SST did not increase during the middle Pliocene when higher latitude sites in the Pacific and Atlantic were experiencing warming. In fact, there is some evidence for minor cooling that, if it can be confirmed through more sensitive analyses and better stratigraphic correlation, would support the hypothesis of increased oceanic meridional heat flow as the mechanism for middle Pliocene warming. The warming estimated at Site 445 is in keeping with warming estimates from Sites 580, 880 , and 883 (Barron 1992, 1995) and 887 (Dowsett and Ishman 1995), and suggests the existence in the middle Pliocene of a strong western boundary current like the modern Kuroshio Current. The results of this study are an important refinement of the original PRISM northern hemisphere reconstruction (Dowsett et al. 1994) and have been incorporated into the first PRISM global reconstruction (Dowsett, Barron, and Poore 1996).

\section{CONCLUSIONS}

All three sites investigated in this study show signs of dissolution which is reflected in both the faunal data and the MAT results. This dissolution appears to be the primary reason for high SCD values. In addition, there is a trend toward higher SCD values with increasing age. Temperatures estimated for Pliocene age samples are reasonable in light of modern conditions in the regions of the core sites, semi-quantitative inspection of the faunal data, and existing knowledge of middle Pliocene North Pacific paleoceanography.

SST estimates for the PRISM time slab are only available from Sites 445 and 769 . At Site 445 peak warm temperatures reach $2^{\circ} \mathrm{C}$ to $4^{\circ} \mathrm{C}$ warmer than today during winter and essentially the same as today during summer, suggesting decreased seasonality. At Site 769 available samples from the lower half of the PRISM time slab show peak winter warmth to be equivalent to modern temperature and peak summer warmth (at most) $0.5^{\circ} \mathrm{C}$ warmer than modern summer. These estimates of warming fit well with estimates derived from other North Pacific sequences.

\section{ACKNOWLEDGMENTS}

We thank Thomas Cronin, Richard Poore, and two anonymous reviewers for their thoughtful comments on this manuscript. Jean Self-Trail, Stephanie West and Sarah Dunn provided valuable technical assistance. We thank the Ocean Drilling Program for providing Deep Sea Drilling Project and Ocean Drilling Program core material. Support for the curating facilities of the Lamont-Doherty Earth Observatory Deep-Sea Sample Repository, from which some core top samples were obtained, is provided by NSF through Grant OCE91-01689 and the Office of Naval Research through Grant N0001490-J-1060. This study is a product of the USGS PRISM Project. 


\section{REFERENCES}

Anderson, D.M., Prell, W.L. and Barratt, N.J. 1989. Estimates of sea surface temperature in the Coral Sea at the last glacial maximum. Paleoceanography, 4(6): 615-627.

Andersson, C. 1997. Transfer function vs. modern analog technique for estimating Pliocene sea-surface temperatures based on planktic foraminiferal data, western equatorial Pacific Ocean. Journal of Foraminiferal Research, 27(2): 123-132.

Barron, J.A. 1992. Pliocene paleoclimatic interpretation of DSDP Site 580 (NW Pacific) using diatoms. Marine Micropaleontology, 20: 23-44.

Barron, J.A. 1995. High resolution diatom paleoclimatology of the middle part of the Pliocene of the Northwest Pacific. Proceedings of the Ocean Drilling Program, Scientific Results, 145: 43-53.

Berggren, W.A., Kent, D.V. and Van Couvering, J.A. 1985. Neogene geochronology and chronostratigraphy, p. 211-260. In Snelling, N.J. (ed.), The Chronology of the Geological Record. London, Blackwell Scientific Publications.

Blow, W.H. 1969. Late middle Eocene to Recent planktonic foraminiferal biostratigraphy. Procedings of the International Conference on Planktonic Microfossils. Geneva, 1967. 1: 199-422.

CLIMAP, 1976. The surface of the ice-age Earth. 191: 1131-1144.

CLIMAP, 1981. Seasonal reconstruction of the Earth's surface at the last glacial maximum. Geological Society of America, Map and Chart Series MC-36: 1-18.

CLIMAP, 1984. The last interglacial ocean. Quaternary Research, 21: 123-224.

Coulbourn, W.T., Parker, F.L. and Berger, W.H. 1980. Faunal and solution patterns of planktonic foraminifera in surface sediments of the North Pacific. Marine Micropaleontology, 5: 329-399.

Cronin, T.M., 1991. Late Neogene marine ostracoda from Tjornes, Iceland. Journal of Paleontology, 65(5): 767-794.

Cronin, T.M. and Dowsett, H.J. 1990. A quantitative micropaleontologic method for shallow marine paleoclimatology: Application to Pliocene deposits of the western North Atlantic Ocean. Marine Micropaleontology, 16(1/2): 117-148.

Dowsett, H.J. 1989a. Application of the graphic correlation method to Pliocene marine sequences. Marine Micropaleontology, 14: 3-32.

Dowsett, H.J. 1989b. Improved dating of the Pliocene of the eastern South Atlantic using graphic correlation: Implications for paleobiogeography and paleoceanography. Micropaleontology, 35(3): 279292.

Dowsett, H.J. 1991. The development of a long-range foraminifer transfer function and application to Late Pleistocene North Atlantic climatic extremes. Paleoceanography, 6(2): 259-273.

Dowsett, H.J. 1996. Middle Pliocene planktonic foraminiferal assemblages from ODP Site 704: palaeoceanographical implications, p. 177-186. In Moguilevsky, A., and Whatley, R. (eds.), Microfossils and Oceanic Environments. University of Wales, Aberystwyth - Press.

Dowsett, H., Barron, J., and Poore, R. 1996. Middle Pliocene sea surface temperatures: a global reconstruction. Marine Micropaleontology, 27: 13-25.

Dowsett, H.J., Cronin, T.M., Poore, R.Z., Thompson, R.S., Whatley, R.C., and Wood, A.M. 1992. Micropaleontological evidence for increased meridional heat transport in the North Atlantic Ocean during 
the Pliocene. Science, 258: 1133-1135.

Dowsett, H.J. and Ishman, S.E. 1995. Middle Pliocene planktonic and benthic foraminifers from the subarctic North Pacific: Sites 883 and 887. Proceedings of the Ocean Drilling Program, Scientific Results, 145: 141-156.

Dowsett, H.J. and Poore, R.Z. 1990. A new planktic foraminifer transfer function for estimating Pliocene through Holocene Sea Surface temperatures. Marine Micropaleontology, 16(1/2): 1-23.

Dowsett, H.J. and Poore, R.Z. 1991. Pliocene sea surface temperatures of the North Atlantic Ocean at 3.0 Ma. Quaternary Science Reviews, 10(2/3): 189-204.

Dowsett, H.J., Thompson, R.S., Barron, J.A., Cronin, T.M., Fleming, R.F., Ishman, S.E., Poore, R.Z., Willard, D.A. and Holtz, T.R. 1994. Joint investigations of the middle Pliocene climate I: PRISM paleoenvironmental reconstructions. Global and Planetary Change, 9: 1-54.

Dowsett, H.J. and West, S. 1993. Pliocene planktic foraminifer census data from Deep Sea Drilling Project Hole 445. U.S. Geological Survey Open File Report (93-307): 5.

Echols, D.J. 1980. Foraminifer biostratigraphy, North Philippine Sea, Deep Sea Drilling Project Leg 58. Initial Reports of the Deep Sea Drilling Project, 58: 567-585.

Emiliani, C. 1955. Pleistocene temperatures. Journal of Geology, 63: 538-578.

Emiliani, C. 1966. Isotopic paleotemperatures. Science, 154: 851-857.

Emiliani, C. 1972. Quaternary paleotemperatures and the duration of the high temperature intervals. Science, 178: 398-401.

Hays, P.E., Pisias, N.G. and Roelofs, A.K. 1989. Paleoceanography of the eastern equatorial Pacific during the Pliocene: A high resolution study. Paleoceanography, 4: 57-73.

Hutson, W.H. 1979. The Agulhas Current during the Late Pleistocene: Analysis of modern faunal analogs. Science, 207: 64-66.

Ikeya, N. and Cronin, T. 1993. Quantitative analysis of ostracoda and water masses around Japan: application to Pliocene and Pleistocene paleoceanography. Micropaleontology, 39: 263-281.

Imbrie, J. and Kipp, N.G. 1971. A new micropaleontological method for paleoclimatology: Application to a Late Pleistocene Caribbean core, p. 71-181. The Late Cenozoic Glacial Ages. New Haven, Yale University Press.

Jenkins, D.G. 1992a. The paleogeography, evolution and extinction of Late Miocene-Pleistocene planktonic foraminifera from the southwest Pacific, p. 27-35. In Ishizaki, K. and Saito, T. (eds.), Centenary of Japanese Micopaleontology. Terra Scientific Publishing Company, Tokyo.

Jenkins, D.G. 1992b. Predicting extinctions of some extant planktic foraminifera. Marine Micropaleontology, 19: 239-243.

Kipp, N.G. 1976. New transfer function for estimating past sea-surface conditions from sea-bed distribution of planktonic foraminiferal assemblages in the North Atlantic. Investigations of late Quaternary Paleoceanography and Paleoclimatology, Geological Society of America Memoir, 145: 3-41.

Klein, G., Kobayashi, K., et al. 1980. Site 445, Daito Ridge, Deep Sea Drilling Project Leg 58. Initial Reports of the Deep Sea Drilling Project, 58: 283-400.

Okada, H. 1980. Calcareous nannofossils from Deep Sea Drilling Project Sites 442 through 446 , Philippine Sea. Initial Reports of the Deep Sea Drilling Project, 58: 549-565. 
Overpeck, J.T., Webb, T. and Prentice, I.C. 1985. Quantitative interpretation of fossil pollen spectra: Dissimilarity Coefficients and the method of modern analogs. Quaternary Research, 23: 87-108.

Parker, F.L. 1962. Planktonic foraminiferal species in Pacific sediments. Micropaleontology, 8: 219-254.

Parker, F.L. 1967. Late Tertiary biostratigraphy (Planktonic Foraminifera) of tropical Indo-Pacific deep-sea cores. Bulletins of American Paleontology, 52: 115-208.

Parker, F.L. and Berger, W.H. 1971. Faunal and solution patterns of planktonic foraminifera in surface sediments of the South Pacific. Deep Sea Resaearch, 18: 73-107.

Polanco, E. and Dowsett, H.J. 1993. Pliocene planktic foraminifer census data from Deep Sea Drilling Project Hole 463 and Ocean Drilling Program Hole 769B. U.S. Geological Survey Open File Report (93-308): 6.

Prell, W.L. 1985. The stability of low-latitude sea-surface temperatures: An evaluation of the CLIMAP reconstruction with emphasis on the positive SST anomalies. Washington, D. C., Department of Energy, 60p.

Rangin, C., Silver, E., et al. 1990. Site 769. Proceedings of the Ocean Drilling Program, Initial Reports, 124: 299-342.

Shackleton, N.J., Hall, M.A., and Pate, D. 1995. Pliocene stable isotope stratigraphy of Site 846. Proceedings of the Ocean Drilling Program, Scientific Results, 138: 337-356.

Shaw, A.B. 1964. Time in Stratigraphy. New York, McGraw Hill, 365p.

Thiede, J., Vallier, T., et al. 1981. Site 463. Initial Reports of the Deep Sea Drilling Project, 62: 33-156.

Thompson, P.R. 1976. Planktonic foraminiferal dissolution and the progress towards a Pleistocene equatorial Pacific transfer function. Journal of Foraminiferal Research, 6(3): 208-227.

Thompson, P.R. 1981. Planktonic foraminifera in the western North Pacific during the past 150,000 years: Comparison of modern and fossil assemblages. Palaeogeography, Palaeoclimatology, Palaeoecology, 35: 241-279.

Vincent, E. 1981. Neogene planktonic foraminifers from the central North Pacific, Deep Sea Drilling Project Leg 62. Initial Reports of the Deep Sea Drilling Project, 63: 329-353.

Willard, D.A. 1994. Palynological record from the North Atlantic region at $3 \mathrm{Ma}$ : vegetational distribution during a period of global warmth. Review of Paleobotany and Palynology, 83: 275-297. 
Figure 1. Scatter diagrams of winter sea surface temperature (SST) $\left({ }_{i} C\right)$ versus squared chord distance (SCD) values between (A.) a modern planktonic foraminifer sample and 223 modern North Atlantic planktonic foraminiferal faunal analyses and (B.) a middle Pliocene sample from Deep Sea Drilling Project (DSDP) Hole 606 and the 223 modern core top samples. Twenty-one counting categories were used in these comparisons. Vertical blue bands indicate standard deviation about mean (shown by arrow) of 10 closest anologs to test samples. Horizontal pink band in lower panel highlights the no analog region of SCD values.

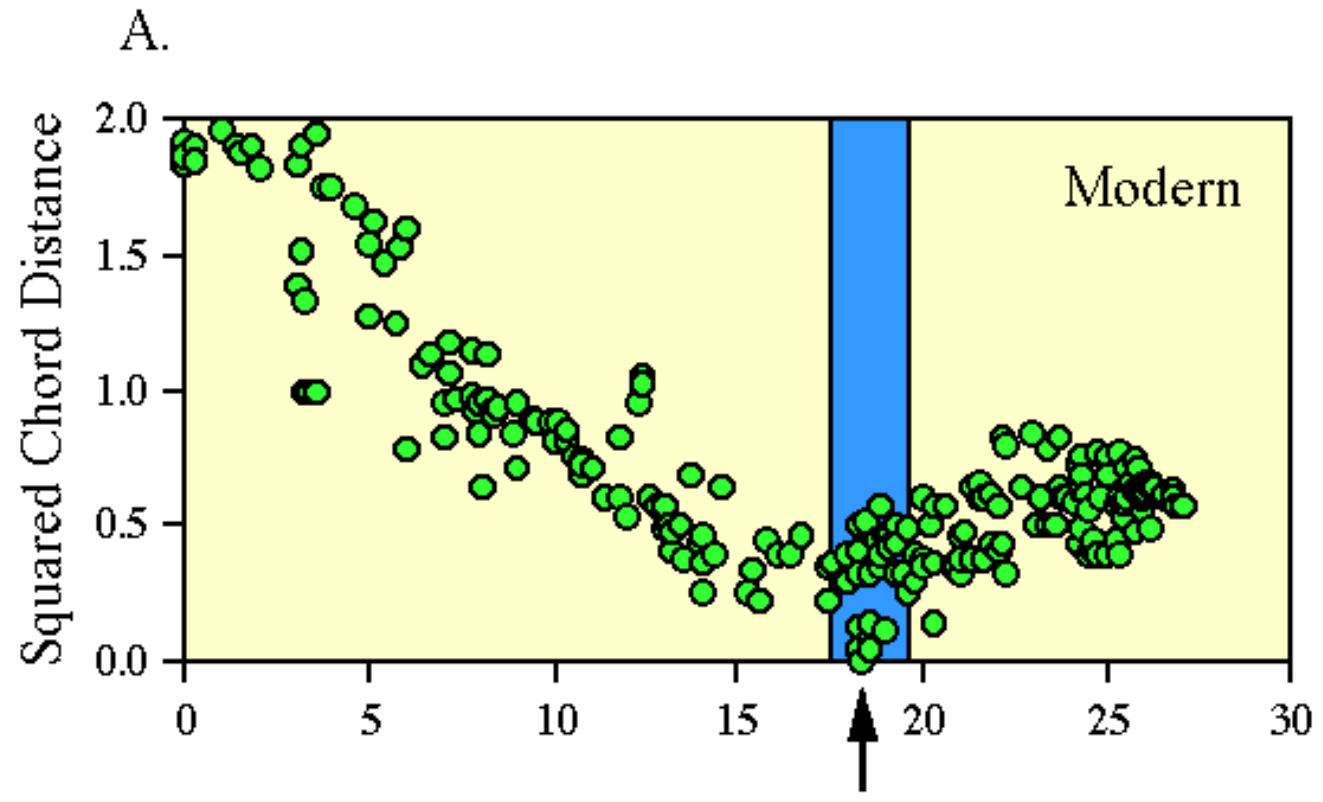

February SST $\left({ }^{\circ} \mathrm{C}\right)$

B.

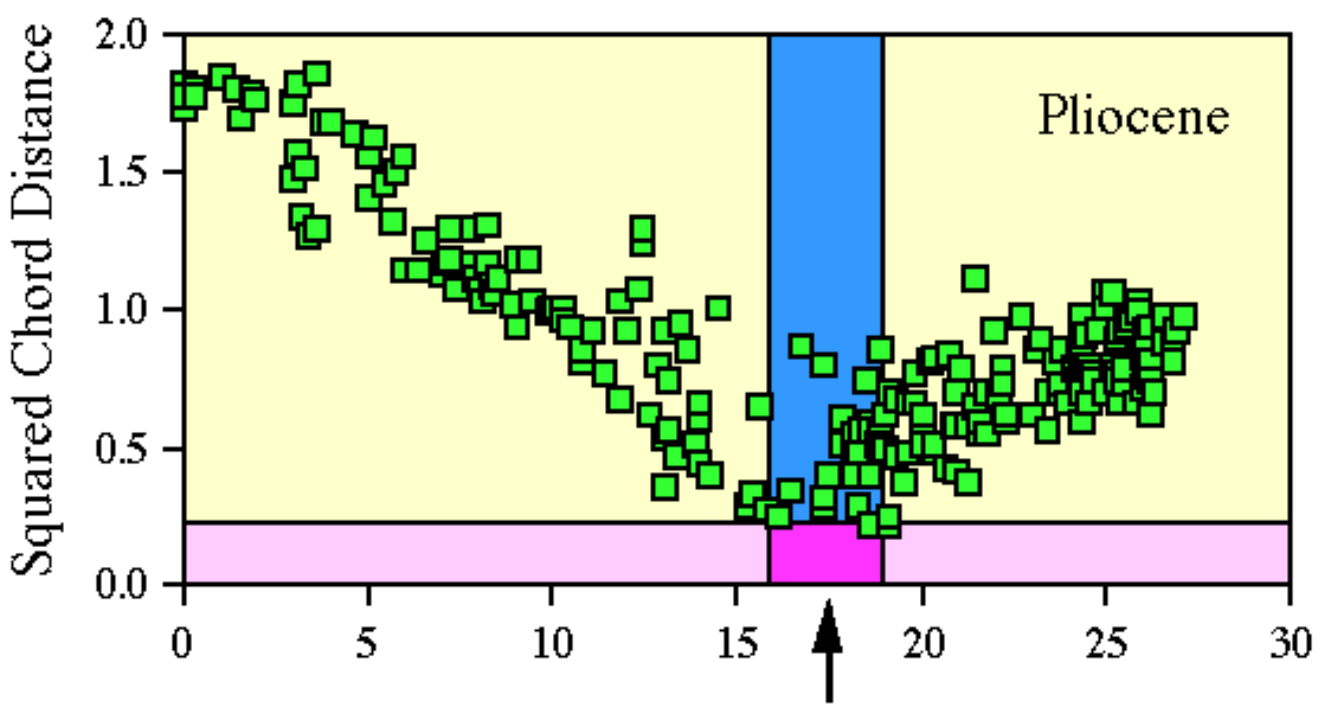

February SST $\left({ }^{\circ} \mathrm{C}\right)$ 
Figure 2. Warm and cold season latitudinal SST gradients for the North Atlantic Ocean. A.) Estimates of modern SST based upon MAT analyses of four core-tops are plotted as points with error bars of 1 standard deviation (s.d.). B.) Estimated Pliocene (2.795 Ma) SST gradients are based upon MAT analyses of four DSDP/ODP Sites in the North Atlantic (see text). Error bars are 1 s.d.
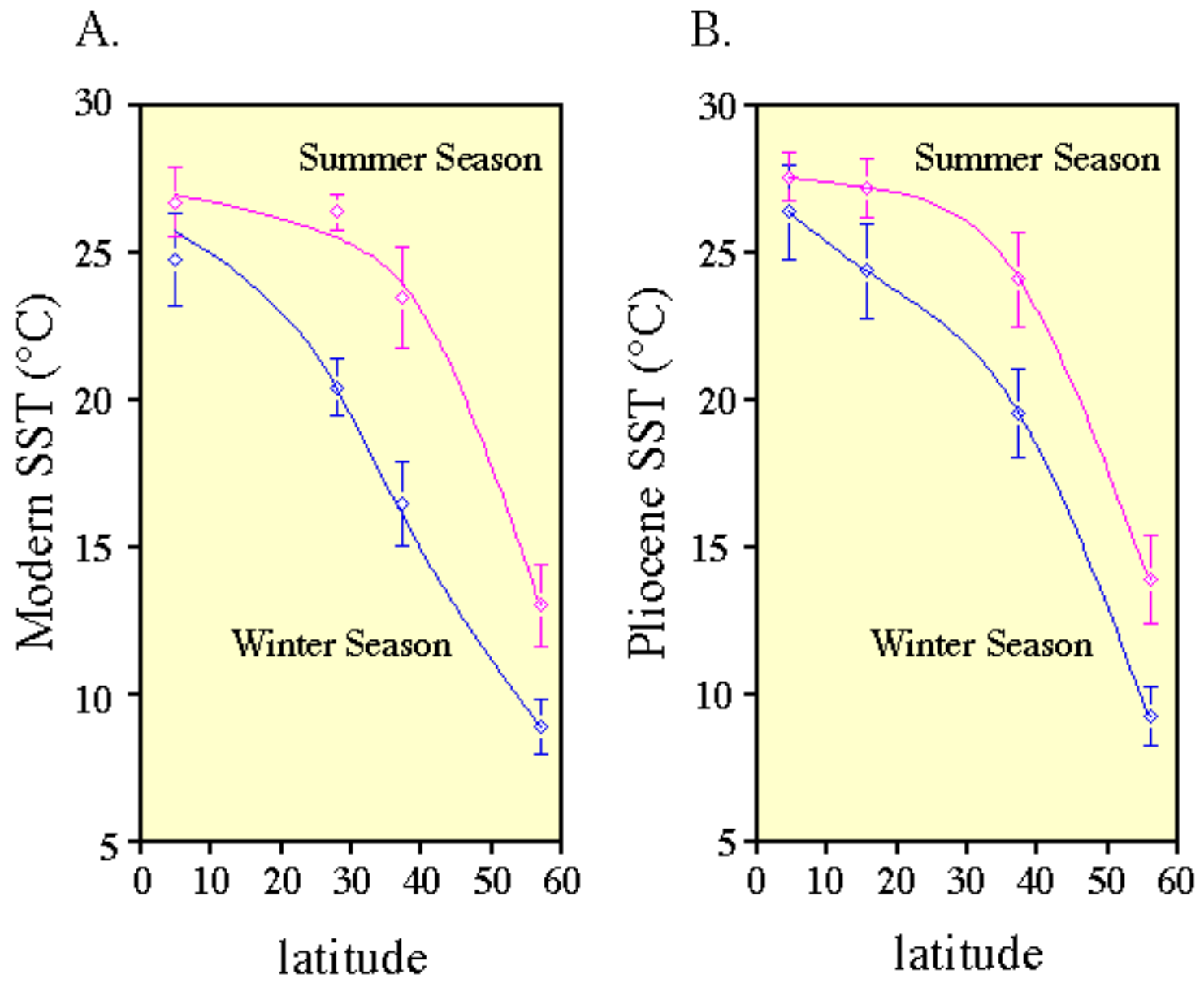
Figure 3. Map of the Pacific Ocean showing the location of Pliocene Sites 445, 463, and 769 and 499 samples with modern planktonic foraminifer data.

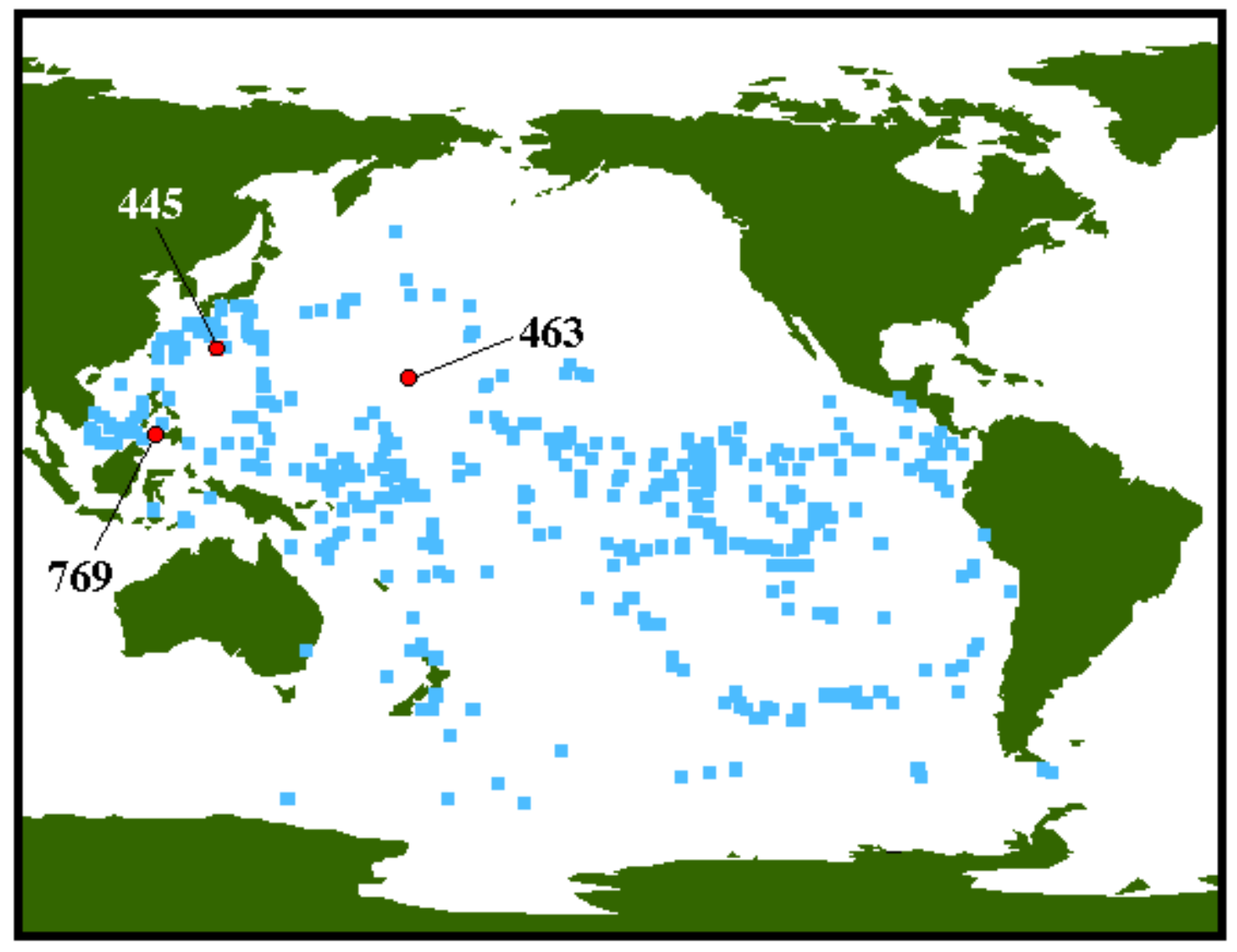


Figure 4. Graphic correlation diagram of DSDP Hole 445 and composite standard reference section of Dowsett (1989a and b). Circles and crosses indicate first and last occurrences respectively.

Composite Standard Reference Section (cu)

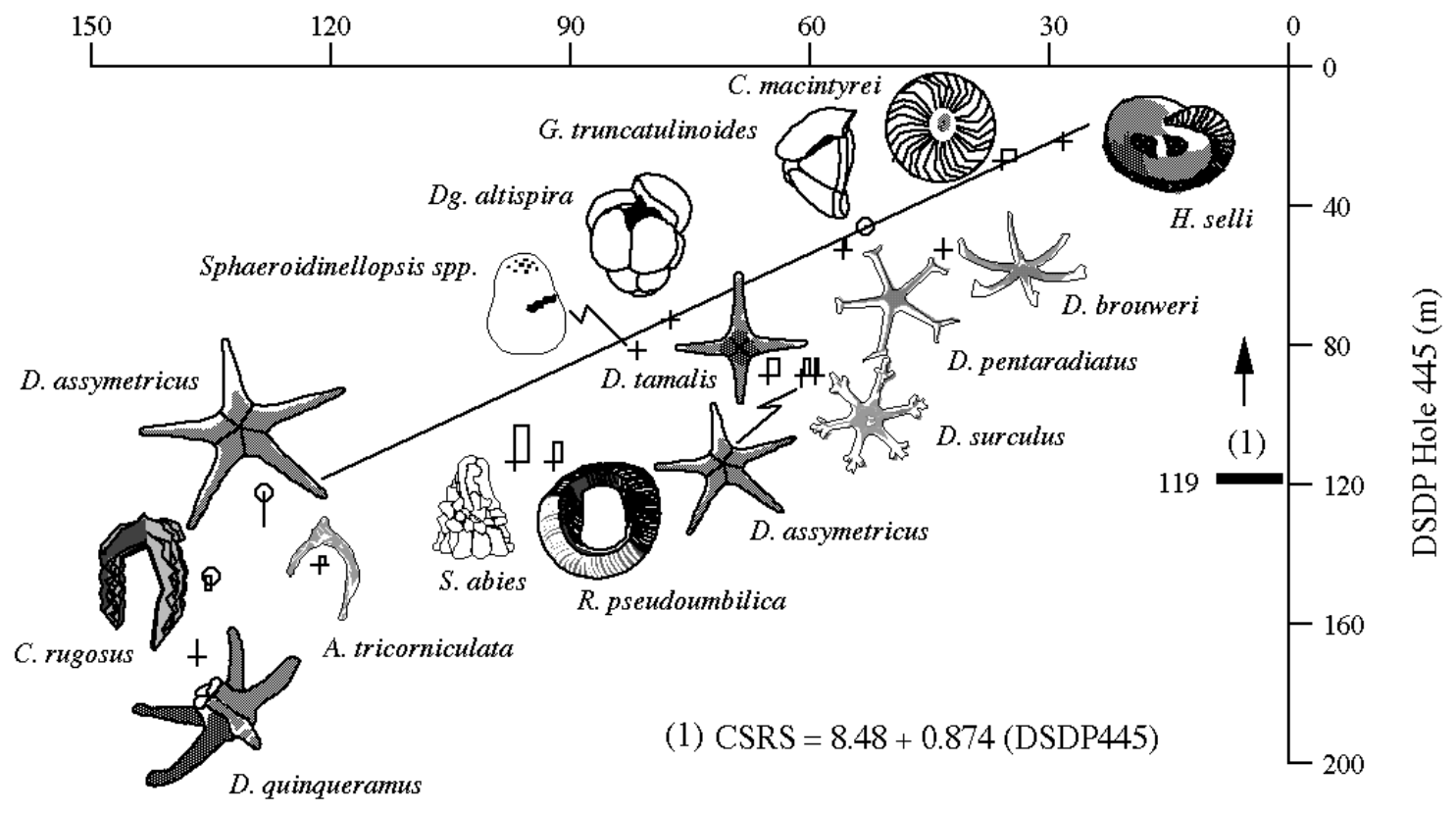


Figure 5. Graphic correlation diagram of DSDP Hole 463 and composite standard reference section of Dowsett (1989a and b). Circles and crosses indicate first and last occurrences respectively.

Composite Standard Reference Section (cu)

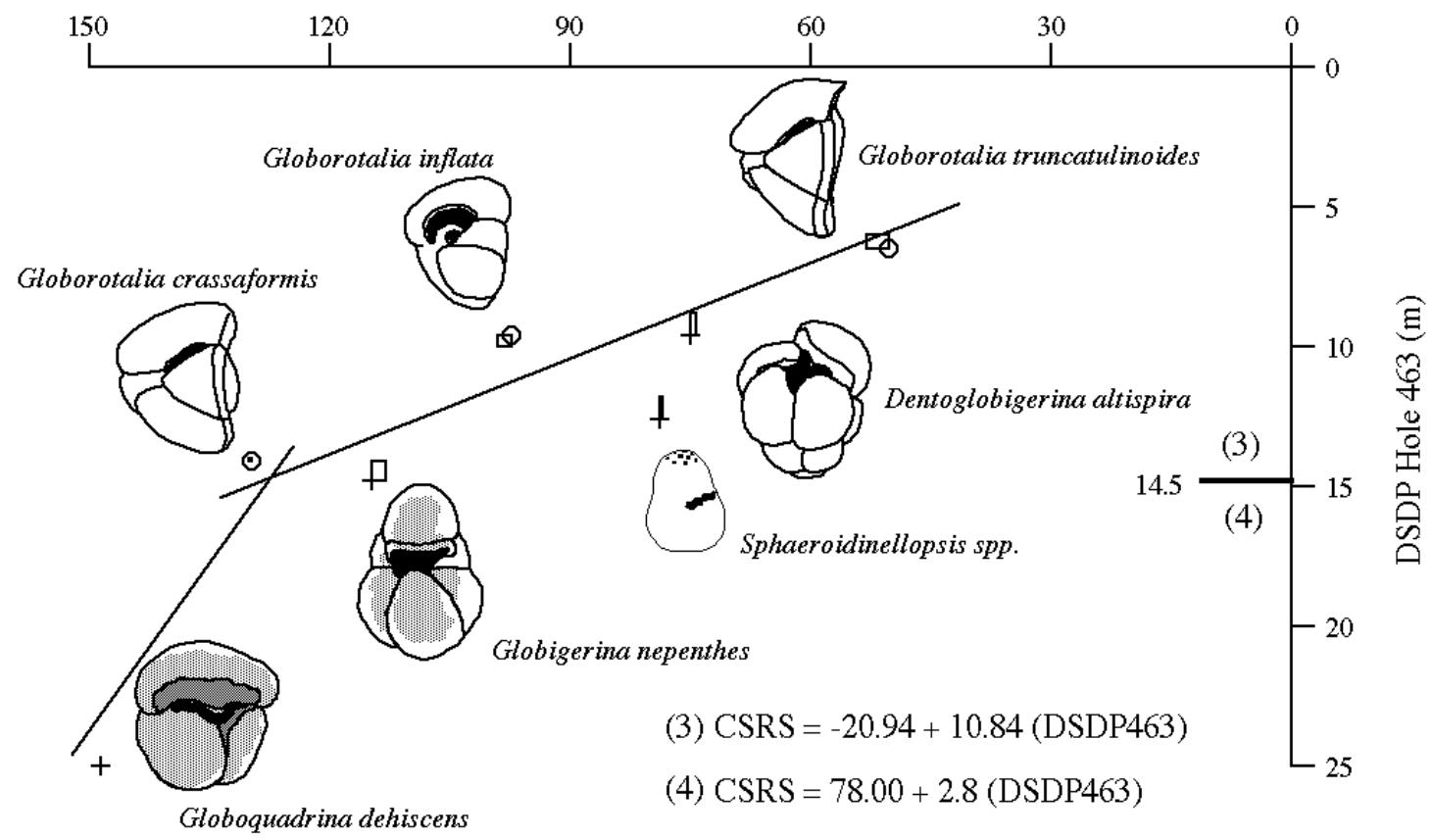


Figure 6. Magnetostratigraphic interpretation of the paleomagnetic record at ODP Hole 769B.

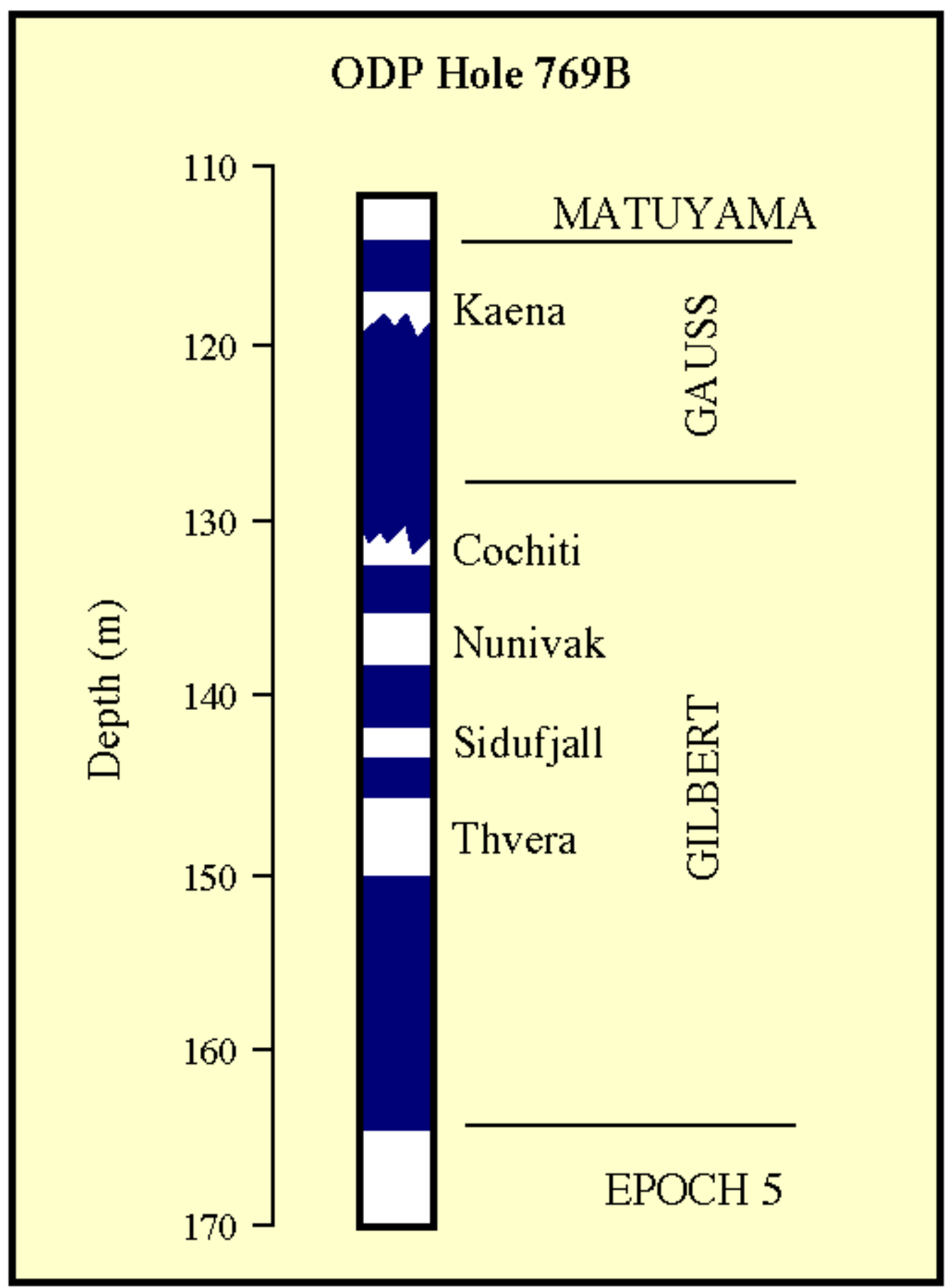


Figure 7. Sea surface temperature estimates (February $=$ Blue, August $=$ Red) for DSDP Holes 445 and 463 and ODP Hole 769, western North Pacific Ocean. Vertical black lines on each time series indicate modern winter and summer SST $\left({ }_{i} \mathrm{C}\right)$. Gray regions labeled "no analog" correspond to samples that have high SCD values and thus SST estimates are not considered reliable. PRISM time slab refers to the time interval between 3.15 Ma and 2.85 Ma (Geomagnetic Polarity Time Scale of Berggren et al., 1985). Error bars are $\pm 1 \mathrm{~s}$.
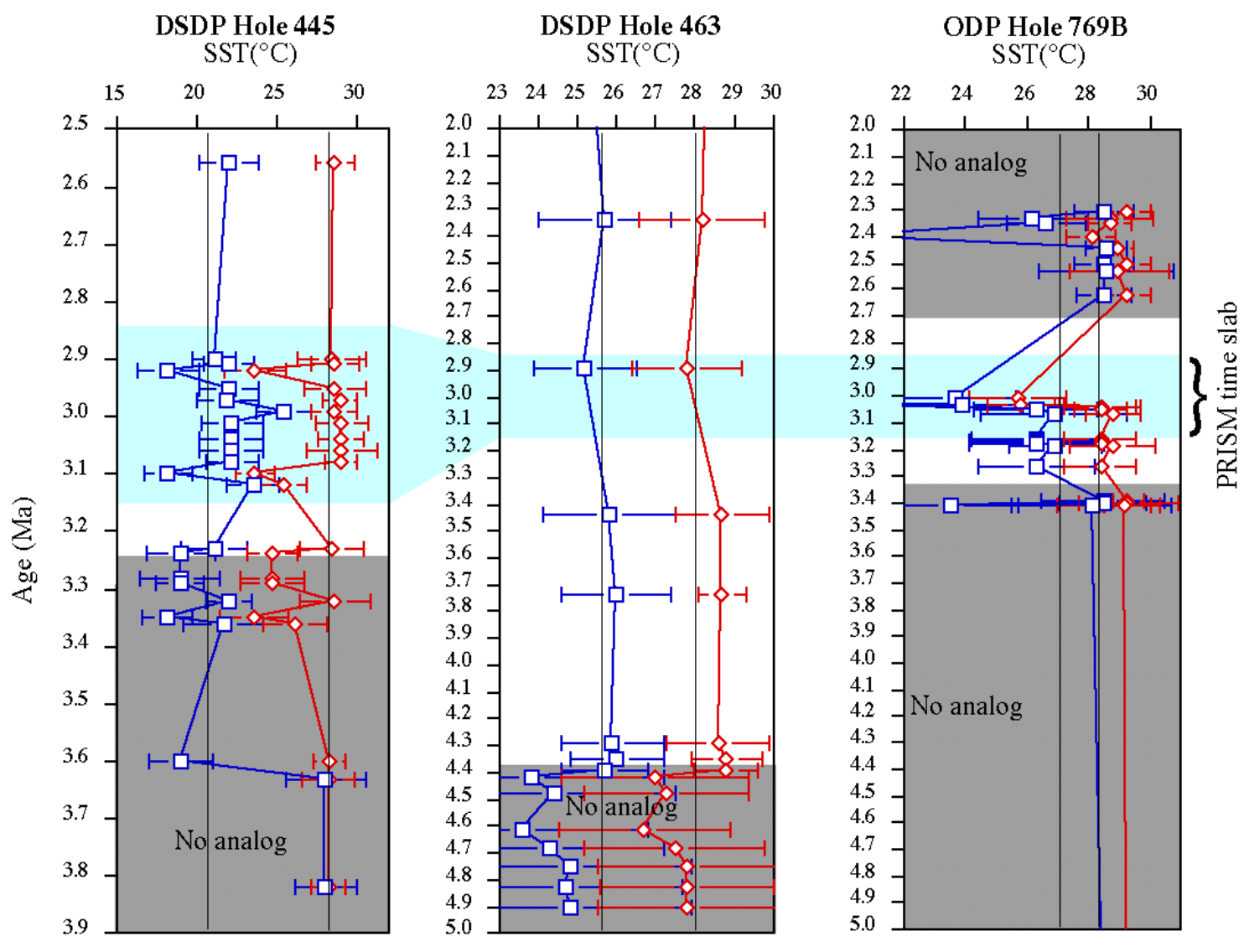
Figure 8. Relationship between Squared Chord Distance (SCD) and dissolution at DSDP Site 445.

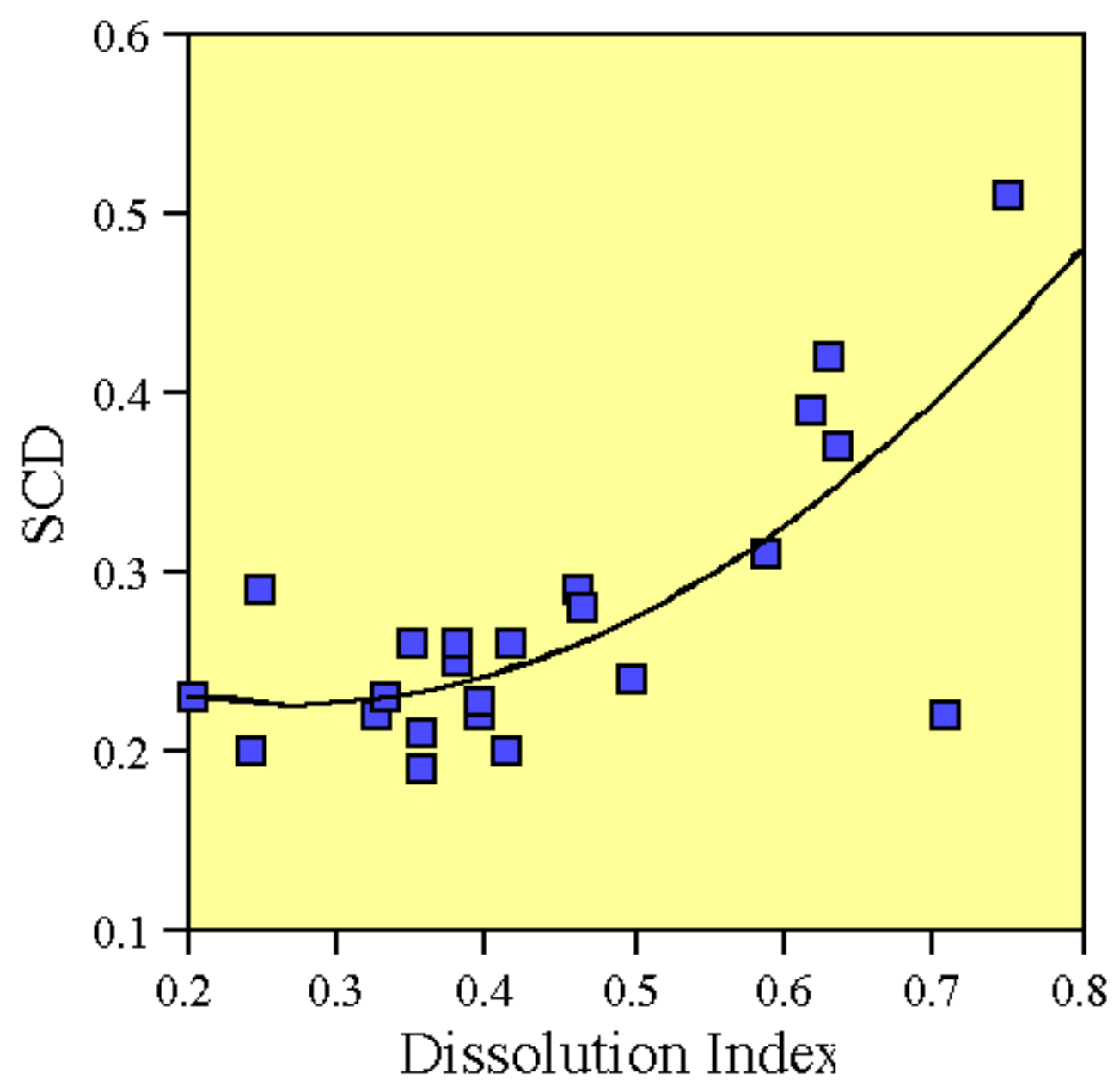

